\title{
THE NATURE OF CHINESE AND RUSSIAN SUBCULTURES IN URBAN DISCOURSE ${ }^{1}$
}

\author{
Olga A. Leontovich \\ Volgograd State Socio-Pedagogical University, Volgograd, Russia; \\ Tianjin Foreign Studies University, Tianjin, China \\ Nadezhda N. Kotelnikova \\ Volgograd State Socio-Pedagogical University, Volgograd, Russia
}

\begin{abstract}
The paper seeks to examine the communicative aspect of modern Chinese and Russian urban subcultures. The nominations of urban social groups representing young people in Russia and China and their connection to modern communication practices are viewed from the perspective of urban communication studies, which provides an opportunity for a new comprehension of issues connected with verbal and nonverbal constituents of urban discourse. The indicates that the subcultures in the Russian urban landscape are reflected in such nominations as фрики (freaki), мажкоры (тајоry), хипстеры (hipstery), брейк-дансеры (break-dancery), байкеры (bikery), etc. The Chinese subcultures are known under such names as shamate, xiaoqingxin, tuyayawenhua, erciyuanyawenhua, egaoyawenhua and many others. We argue that in both countries the unity of social subgroups is based not so much on ideological preferences, but rather on lifestyles, hobbies and interests, many of them formed under the Western influence. The subcultures discussed in the research represent a broad panorama of Chinese and Russian social life. They reflect the sociocultural dynamics of attitudes, values and lifestyles influenced by globalization but acquiring nationally specific features, which transform them into unique sociocultural phenomena.

Key words: subcultures, nominations, China, Russia, urban communication studies.

Citation. Leontovich O.A., Kotelnikova N.N. The Nature of Chinese and Russian Subcultures in Urban Discourse. Vestnik Volgogradskogo gosudarstvennogo universiteta. Seriya 2. Yazykoznanie [Science Journal of Volgograd State University. Linguistics], 2021, vol. 20, no. 5, pp. 87-96. DOI: https://doi.org/10.15688/ jvolsu2.2021.5.7
\end{abstract}

УДК 81’42:003.074

Дата поступления статьи: 22.03.2020

ББК 81.055 .51 .3

Дата принятия статьи: 07.06.2021

\section{КИТАЙСКИЕ И РОССИЙСКИЕ СУБКУЛЬТУРЫ В КОНТЕКСТЕ МЕДИАУРБАНИСТИЧЕСКОГО ДИСКУРСА ${ }^{1}$}

\section{Ольга Аркадьевна Леонтович}

Волгоградский государственный социально-педагогический университет, г. Волгоград, Россия; Тяньцзиньский университет иностранных языков, г. Тяньцзинь, Китай

\section{Надежда Николаевна Котельникова}

Волгоградский государственный социально-педагогический университет, г. Волгоград, Россия

Аннотация. Статья посвящена изучению современных китайских и российских субкультур в коммуникативном аспекте. Номинации молодежных социальных групп в китайских и российских городах, а также связанные с ними коммуникативные тактики рассмотрены с позиций медиаурбанистики, что дает возможность по-новому осмыслить проблемы структуры городского дискурса - соотношение его вербальной и невербальной составляющих. Выявлено, что российские субкультуры отражены в таких номинациях, как фрики, мажоры, хипстеры, брейк-дансеры, байкеры и т. д.; китайские, в свою очередь, известны под такими названиями, как 杀马特 shamate, 小清新 xiaoqingxin, 涂鸦亚文化 tuyayawenhua, 二次元亚文化 erciyuanyawenhua, 恶搞亚文化 egaoyawenhua и др. Установлено, что в обеих странах единство социальных 
групп определяется не столько идеологическими факторами, сколько стилем жизни, увлечениями и интересами, многие из которых сформированы под влиянием Запада. Обсуждаемые субкультуры представляют широкую панораму жизни большого города в России и КНР. В них отражается динамика менталитетов, ценностей и образа жизни, складывающихся в условиях глобализации, но обретающих национально-специфические черты, трансформирующие их в уникальные социокультурные сообщества.

Ключевые слова: субкультуры, номинации, Китай, Россия, медиаурбанистика.

Цитирование. Леонтович О. А., Котельникова Н. Н. Китайские и российские субкультуры в контексте медиаурбанистического дискурса // Вестник Волгоградского государственного университета. Серия 2 , Языкознание. - 2021. - Т. 20, № 5. - С. 87-96. - (На англ. яз.). - DOI: https://doi.org/10.15688/jvolsu2.2021.5.7

\section{Introduction}

The pulsating rhythm of urban life, its polyphony and diversity which are nowadays experienced by over half of humankind, define the key principles and strategies of human interaction, power relations and tendencies of social development. This enhances the significance of urban studies carried out in different fields of knowledge, such as architecture, sociology, political science, economics, communication studies, linguistics, etc. There is a great increase of the volume of publications, conferences and symposiums tackling the nature and contextualization of urban discourse.

The purpose of this paper, which constitutes part of a broader investigation entitled "Language of a Big City: Media Urban Discourse in Russia and China" and supported by the Russian Foundation for Basic Research, is to examine the communicative aspect of modern Chinese and Russian urban subcultures.

\section{Theoretical background and research methods}

The study draws from a number of theories dealing with urban life and represented in the works by Simmel [1903/1950], Weber [1922/1978; 1923/1966], Mellor [1977], etc. (see a detailed review in: [Encyclopedia of Urban Studies, 2010; Kvyat, 2014; Parker, 2015]). The founders of Russian urban studies termed as gorodovedeniye or gradovedeniye are the historians Grevs and Antsiferov (as cited in: [Yunakovskaya, 2011]).

Modern authors are trying to give new interpretations of the concepts city and the urban taking into account the realities and rhythms of contemporary life. Aiello and Tosoni [2016, p. 1253] differentiate between city as context, city as medium and city as content, the combination of which constitutes a city as a source and product of interactions, practices and narratives. Scholars believe that the term the urban embodies social practices, networks and patterns of interpersonal and intergroup communication. The new times are marked by the emergence of such notions as creative cities and smart cities [Aurigi, 2005, 2012; Pratt, 2011]. The proponents of the so called new urbanism promote the ideas of the creation of open urban space, context architecture, green zones, reasonable balance between office and residential buildings, reduction of transportation flows, preservation of historical buildings, etc. (for example see: [The Charter of the New Urbanism]).

The urban landscape is traditionally understood as a physical environment - houses, streets, squares, engineering constructions, etc. A different approach is suggested by Lefebvre [1991] who interprets a city as a live organism and indicates that space is not anything given by nature and permanent but constantly developing and reproduced on the basis of social change. He delineates physical, mental and social space and writes about multiple definitions of space - geographical, economic, demographic, sociological, political, etc. Contemplating the role of language in an urban landscape, Lefebvre poses the following questions: does language logically, epistemologically and genetically precede the construction of social space or is it its product? How is space read and decoded? The author comes to the conclusion that space is a sort of surcodage, code des codes (code of codes) [Lefebvre, 1991, pp. 20-27].

Lefebvre's definitions applied to urban communicative space can act as a foundation for investigating it from different perspectives, such as the territorial organization of space, its configuration, road networks, correlation between the city centre and peripheries, built and unbuilt urban space, division into communities as a result of 
social segregation, special distribution of languages and sociolects, philosophy of environmental conservation, etc. [Leontovich, 2020].

The application of the notion border to urban society allows scholars to research the boundaries between communities, languages, dialects, cultures and subcultures, (im)possibility of crossing them and the connection between space and identity. The notion of space is also related to the problems of (in)equality, existence of poor and rich housing, prestigious and unprestigious areas, as well as the controversial character of urban space [Leontovich, 2020; Tarantino, Tosoni, 2013]. The investigation of a big city from the perspective of media urban studies provides an opportunity of a new comprehension of issues connected with verbal and nonverbal constituents of urban discourse.

Our research is based on the principles of critical discourse analysis, narratology, semiotics and urban communication studies which have been fruitfully applied to the study of different aspects of urban discourse [Bakumova, Kotelnikova, 2019; Chen, Leontovich, 2020; Kotelnikova, 2019; Leontovich, 2018; 2020], such as historical memories and their reflection in the urban landscape, the correlation between public discourse and the citizen's private life, social advertising as a reflection of universal and culturally specific values, ethnic, cultural and linguistic diversity of urban communication, new urban communicative practices, the reflection of the COVID-19 pandemic in Russian and Chinese media urban discourse, etc.

The present paper discusses the new nominations of urban social groups representing young people in Russia and China and their connection to modern communication practices. The research employs the methods of definition analysis, discourse analysis, semiotic analysis and contextual analysis. We argue that in both countries, the unity of social subgroups is based not so much on ideological preferences, but rather on lifestyles, hobbies and interests, many of them formed under the Western influence.

\section{Discussion}

A high degree of diversification typical of a big city accounts for the emergence of new social groups and is reflected in language in the form of a broad semantic class of words nominating social groups. It is developed on the basis of numerous differential elements such as age, gender, profession, ethnicity, etc. The city is interpreted as a real and abstract (imagined) community (e.g. citizens, city authorities, creative elite). The interaction in an urban context happens on the level of interpersonal and group communication, as well as between an individual and urban community, city administration, mass media and so on.

On the one hand, the image of a city is formed on the basis of its citizens' collective identity; on the other hand, the city influences peoples' individual identity defining them as inhabitants of Moscow, Volgograd, Beijing, Tianjin, etc. Social advertising can act as a significant visual factor affecting the citizens' mind and expressing universal and culturally specific values. Every city is characterized by the existence of certain communication patterns and networks typical of local urban communities (districts, yards and youth groups); fluctuation between various language codes and repertoires; different forms of urban activism and the contribution of urban practices to the formation of different subcultures.

Subcultures have been analysed from different perspectives [Fine, Kleinman, 1979; Hall, Jefferson, 2006; etc.]. The common approach among Russian scholars [Gurevich, 1998; Levikova, 2007; Omelchenko, 2000; Sikevich, 1990] is to view them as part of national culture, with their own systems of values, norms, customs, traditions, behavior and lifestyle. Chinese researchers give similar definitions to the notion of 'subculture' (亚文化) but emphasise that it is an alternative to dominant culture displaying some deviations from it without denying its essence [高丙中, 1997, p. 113; 许苏民, 1990, p. 145].

In contemporary society, there is a tendency to view subcultures not as integral ways of living and mindsets, but rather recreational practices and virtual communities [Galushina, 2016, c. 134]. If a while ago it was common to belong to one subculture, nowadays it is normal to be part of several subcultures at a time, which means that the notion of subculture has been replaced by a 'cultural mix'. The 'post-subcultural theory' accommodates the "increasing fragmentation of youth style since the 1980s" [Bennett, Kahn- 
Harris, 2004, p. 2] and the specifics of the postmodern state of society and culture. According to this approach, the hard and fast lines between subcultural divisions have dissolved and identity has become less outwardly apparent [Bennett, Kahn-Harris, 2004, p. 2]. The elements of different styles are mixed and modern subcultural identity does not replace but rather supplements mainstream social existence.

Bakumova and Kotelnikova [2019] have described a number of new nominations of Chinese subcultures reflecting modern trends in society. They are predominantly formed with the help of a highly productive suffix morpheme 族 of Japanese origin, which denotes a group of people united by a general characteristic or activity [王晓静, 2010; 肖遥遥, 2009]. The neologisms based on the 《X 族》 pattern often include borrowed elements, which testifies to the influence of globalization processes in Chinese society. A good example is the word 辣奢族, the initial component of which is 辣奢 lashe - a phonetic calque from the English word 'luxury'. The lexeme 辣奢族 is used to denote young people born in the 1980s - 90s, mostly with a good income, who strive to live a life of luxury and are trying to emphasise their social status by means of different accessories. Their consumerism is based on the obsession with fashionable brands, even if it contradicts common sense. Other examples in this group of nominations are: 乐活族 lashezu (people leading a healthy lifestyle) stemming from the English abbreviation LOHAS (lifestyle of health and sustainability); 尼特族 nitezu (a 'no-no generation' - young people who don't work or study) derived from the English acronym NEET (Not in Employment, Education or Training); 飞特族 feitezu (so called 'free workers' - young people who do not have a permanent job and live on occasional earnings) based on the combination of the English word free and German arbeiter [Bakumova, Kotelnikova, 2019; 肖遥遥, 2009; 王思妮, 2010; 流响, 2014].

A very different social group is 蚁族 yizu ('ant tribe') applied to young people in their twenties, recent university graduates, mostly from agricultural areas or smaller cities who come to Chinese megacities in order to climb the social ladder [赵声馗, 2014]. Because of their low income, they have to live in apartments with numerous lodgers or in old barracks divided into tiny rooms at the outskirts. From every point of view, they remind ants: they are intelligent, hard-working and live in colonies [Bakumova, Kotelnikova, 2019; Wu Yao, 2017].

The name of another social group that has been rapidly growing is 月光族 yueguangzu (from 月 - month; 光 - completely, to the last bit) - a collective nomination for those who spend their monthly income to the last mao. Their characteristic feature is not so much the their low income but rather inability to spend their money wisely. This social group is mostly composed of people who grew up without brothers or sisters under the one-child policy, representative of the generation of 'little emperors', consumers living under the slogan: “赚多少花多少” (Spend as much as you have earned) and differ a lot from the older generation of the Chinese who are very frugal and tend to save money. Another neologism that is acquiring popularity is 月欠族 (月 - month; 欠 - lack, owe), used to denote people who cannot control their spendings, and use online banking to borrow more money that they can earn [Bakumova, Kotelnikova, 2019; 张洪涛, 2019; “月光族”..., 2019].

The high cost of living in megacities has produced a social group called 钟摆族 zhongbaizu ('pendulums'). These are commuters who work in central parts of the city but choose to buy apartments in the outskirts of the city or beyond. The use of the metaphorical image of a pendulum reflects the peculiarities of their life [曾丹, 2010]. China possesses a well developed transportation system, including high-speed railway lines, which contributes to the growth of this social group. All those terms which originated in the internet have become widely used due to mass media.

Both Russian and Chinese megacities are huge sites which provide young people with broad opportunities of self-realization and an endless potential for the formation and development of youth subcultures. As was mentioned above, the consolidating factors are lifestyles, hobbies, interests, etc, rather than ideological preferences. What we could observe during our study was that this landscape is extremely dynamic and rapidly changes: what used to be seen as fashionable yesterday, is no longer perceived as such. The study also shows the fluidity of new subcultures and a lack of distinct boundaries between them. 
The subcultures in the Russian urban landscape are reflected in such nominations as фрики (freaki), мажсоры (тајоry), рейверы (ravery), xuncmepbl (hipstery), xun-хоперы (hiphoppery), брейк-дансеры (break-dancery), байкеры (bikery), панки (punki), рэперы (rappery), футбольные фанаты (football fanaty), экологиcmы (ecologisty), ролевики (roleviki), толкиениcmbl (tolkienisty), ЭМО (ЕMO), аниме (anime), готы (gothy), сатанисты (satanisty), etc., most of them evidently stemming from corresponding English words and Western communication practices connected with street art, graffiti and role quests. In many instances they acquire culturally specific features induced by the Russian urban environment. For example, in the 1950s hipster subculture associated with alternative fashion, art, music and films, was adopted in Russia in the form of stilyagi and revived after the release of the 2008 cult film with this title.

Specifically Russian communication practices are reconstructions of historical events, 'posidelki', 'kvartirniki' and 'anti-cafés' (see also: [Kvyat, 2013; Leontovich, 2019]).

Some of the subcultures mentioned above, such as hip-hoppers and break-dancers, are to a certain extent represented in the Chinese urban landscape. In most cases they are, however, transformed under the influence of the Chinese social context. For example, the Chinese counterpart of hipster subculture is 文艺青年 wenyiqingnian (lit. 'cultured young people', or 'art-loving young people').

A subculture similar to freaks is 杀马特 shamate, which emerged in China at the dawn of the $21^{\text {st }}$ century. The nomination stems from the English word smart and denotes young people aged from 16 to 25 years old with basic secondary general or technical school education, coming from rural areas to big cities in order to earn money. Unlike earlier migrants, they are not ready for hard physical labour on construction sites and are happy to find low-paid jobs at factories, hairdressers, grocery stores and delivery services. They are conspicuous because of their flamboyant style, bleached or brightly dyed and teased hair, with lots of hairspray, bright make-up, nails and piercing, unusual loud clothes and plenty of accessories. The shamate subculture has been largely influenced by western informal trends, but, unlike them, is devoid of the rebellious spirit and denial; their only wish is to attract attention by their unconventionality and extravagance. They are eager to capture their bright appearance by taking selfies and posting them on closed chats of the Chinese QQ messenger where they communicate with other subculture members. This is the most disliked and scorned subculture in China ridiculed in real life and on the Internet. They do not want to go back to their villages but cannot find their place in the city. Shamate are young provincials without any financial or social support who, on the one hand, strive for selfrealization and want to attract attention by their appearance and, on the other, want to be accepted by the urban community [王福帅, 杨阳, 2014; Kotelnikova, 2019].

Shamate subculture is usually juxtaposed to 小清新亚文化xiaoqingxin subculture. The term 小清新 is composed of the words 小 (small) and 清新 (fresh). It has been influenced by the indipop music and the works by the female Chinese novelist Li Jie, who publishes on the Internet under the pen-name 安妮宝贝 Anni Baobei and is extremely popular among young people. The representatives of the xiaoqingxin subculture are predominantly young educated women from wellto-do families with versatile interests, exquisite tastes and positive world perception. They enjoy artwork, travelling alone, certain tastes in music and cinema. They like a certain style in clothes (long linen skirts, checkered shirts, canvas shoes and absence of bright make-up). An important accessory is a LOMO camera - photography is an important form of self-expression which gives them an opportunity to capture the beauty of the world, find magic in mundane existence and share their thoughts and feelings. They usually have their personal pages and blogs in social networks where they publish their photographs and literary essays. Xiaoqingxin are romantic dreamers who oppose themselves to mainstream culture. However, due to the attention of mass media and public approval, this subculture has become so popular and has acquired so many imitators that it runs the risk of becoming mainstream itself [刘黎黎, 2013, pp. 72-73].

二次元亚文化 erciyuan yawenhua (2D subculture) unites the admirers of twodimensional animation and computer games in the Japanese style anime comics. In Russia this subculture is often called by the Japanese word 
otaku. The word 御宅族 yuzhaizu is actively used in Chinese, however, it is applied to young people who live a lonely life, avoid real contacts and spend all their free time on the internet [ 谯燕, 2012, p. 5]. The literal translation of the word otaku is 'your home', so its etymology explains this usage. Undoubtedly, the representatives of the 2D subculture include people who can be called otaku, but the 2D subculture itself does not presuppose confinement and a secluded life style. It has plenty of followers in China - 153 million fans (二次元迷), each of them spending around 1700 yuans a year on goods connected with anime, which gives a strong impulse to the development of 2D industry. According to the statistical information published by the Chinese biggest media platform “Sina Weibo" (新浪微博), the age of the $2 \mathrm{D}$ fans is very diverse. The representatives of this subculture have no common ideology - they are just interested in certain media products. They are also characterized by the use of a common slang - mostly words borrowed from Japanese and usually emotionally coloured. The representatives of the 2D subculture hold numerous events which provide broad opportunities for offline communication: anime-festivals, exhibitions, thematic parties, etc. Some of them are held on an amazingly huge scale. For example, in 2017 "The Chinese International Anime Festival" annually held in Hangzhou city, united participants from 82 countries of the world. During six days the festival was attended by over 1.39 million people [139 万..., 2017]. One of the new communication practices associated with 2D subculture is 动漫角色扮演 - cosplay (abbreviated from 'costume play') - a game in which anime and computer game characters are personified not only through their appearance but also their behaviour, manner of speech, phrases and gestures. Some of the representatives of 2D subculture copy their favourite characters not only in cosplay, but also in everyday life.

Graffiti subculture is popular both in Russia and China. It is formed by graffiti writers whose solidarity is based on their interest for wall art and the desire to express an idea or produce an emotional response in the spectators with the help of compositions painted on urban constructions. The Russian graffiti movement which originated in the USSR in the 1980s, acquired mass character by the late 1990s and is still on the rise. It is interesting to note that the annually held street art festival bears the name "SNICKERS URБANия"; its unusual spelling being an example of creative language use.

In China the representatives of graffiti subculture (涂鸦亚文化 tuya yawenhua) are not so numerous as some others, however, their artistic activities have a great influence on the image of Chinese cities. The Chinese version of subculture emerged in Beijing in 1996 after the penetration of hip-hop to China and at first was disapproved of by city dwellers. It is not without reason that originally this type of street art was called 涂鸦 tuya, which literally means 'to smudge crows' or 'scribble'. This word stems from an old poem by Lu Tong (VIII-IX century) devoted to his little son who often smudged his books with ink. At present the art of graffiti has acquired popularity, and in big cities there are special walls assigned for graffiti writers. For example, the authorities of Chongqing city have dedicated a whole street Huangjueping (黄桷坪涂鸦街) for graffiti. Thirty-seven buildings with a total space of 50 thousand square meters in that street are covered with colourful art. This street is one of the biggest graffiti projects not only in China but in the whole world. However, in big Chinese cities the artistic self-expression of graffiti writers outside special zones in not welcomed and is seen as damage to the urban landscape [庞彦, 2011, p. 183]. That is why the modern tendency is the relocation of street art to the internet. Many graffiti writers create their works primarily in order to photograph them and post them on the internet so that a short-lived piece of art could continue its life online [Kotelnikova, 2019, p. 29].

In modern information society, online communication, including social networks and internet forums, has become an urgent need for people both in Russia and China. As a consequence, we can observe the emergence of internet subcultures which have acquired their own systems of values, language, manner of behaviour and other representations. At present the global network houses numerous internet subcultures, the most popular of which in both countries are gamers, bloggers, huckers, trolls, etc.

One of the most widely spread Chinese internet subcultures is egao (恶搞亚文化) formed by means of morpheme contraction from the word combination 恶意搞笑 (to joke viciously). 
Chinese sociologists apply the term egao to the practice of changing famous literary works, films, songs, videoclips, advertisements or imitating a celebrity by means of parody, collage, hyperbole, etc. in order to achieve a comic effect [胡疆锋, 2008, p. 5; 张林, 2014, p. 338]. The result can be represented in the form of text, audio- or video material, photography or comics presented on the internet. The proliferation of this subculture was facilitated by such programs as Photoshop and Premiere, available for wide masses of internet users. Egao became so popular in China that it spread from the internet to television, newspapers and magazines. The egao subculture is predominantly represented by young people displaying critical, ironic or sarcastic perception of reality. Egao personifies the Chinese version of freedom of speech; however, its representatives produce contradictory impressions on the public. According to the results of a sociological survey carried out by "The Chinese Youth Newspaper", $89,9 \%$ of respondents believe that there should be certain limits - tabooed topics which cannot be ridiculed, such as national heroes [蔡骐, 谢芗, 2008, p. 50].

The discourse analysis of Russian and Chinese subcultures also yields information about attitudes towards particular social groups. For example the Russian term majory (young people whose influential parents provide them with money and social benefits) has a negative connotation, as well as the Chinese nomination 土豪 tuhao denoting the uncouth new rich who are fond of golden iPhones and expensive cars decorated with Swarovski crystals. The latter is juxtaposed to the positively marked terms 高富帅 gaofushuai (lit. tall, rich, hansome, 'prince on a white horse') denoting an educated rich man with high social standing, and 白富美 baifumei (lit. white, rich, beautiful) - an attractive young woman with good manners and lots of money.

Subcultures form networks in which people are connected with each through different communication channels. The internet provides practically unlimited opportunities for such communication. The sign of our time is the transfer from interpersonal to technologically mediated communication. However, it is possible to notice a reverse process - from internet-based to offline forms of interaction. The changes in discourse patterns are associated with the growth of a new generation, with its own aspirations, perception of the environment and desire for social changes - all the factors that have a profound effect on contemporary urban life and its semiotic representation.

\section{Final considerations}

The subcultures discussed in our research are only a fraction of the urban mosaic representing a broad panorama of Chinese and Russian social life. They reflect the sociocultural dynamics of attitudes, values and lifestyles. Modern big cities as a complex medium of socialization are becoming more tolerant of differences in multiple forms of people's behaviour. Globalization processes, mostly under the western influence, and the integration of cities into the world cultural space account for their universal character; however, they acquire nationally specific features transforming them into unique sociocultural phenomena.

\section{NOTE}

${ }^{1}$ The reported study was funded by the Russian Foundation for Basic Research according to the research project № 17-29-09114.

Исследование выполнено при финансовой поддержке РФФИ в рамках научного проекта № 17-29-09114.

\section{REFERENCES}

Aiello G., Tosoni S., 2016. Going About the City: Methods and Methodologies for Urban Communication Research - Introduction. International Journal of Communication, vol. 10, pp. 1252-1262.

Aurigi A., 2005. Making the Digital City. Aldershot, Ashgate Publ. 236 p.

Aurigi A., 2012. Reflections Towards an Agenda for Urban-Designing the Digital City. Urban Design International, vol. 18, iss. 2, pp. 131-144.

Bakumova E., Kotelnikova N., 2019. Linguistic Expression of the Social Stratification of Chinese Urban Society. SHS Web of Conferences (The International Scientific and Practical Conference "Current Issues of Linguistics and Didactics: The Interdisciplinary Approach in Humanities and Social Sciences" (Volgograd, April 23-28, 2019)). Volgograd, s. n. Vol. 69. DOI: $10.1051 /$ shsconf/20196900011.

Bennett A., Kahn-Harris K., 2004. After Subculture: Critical Studies in Contemporary Youth Culture. 
Basingstoke, Hants., New York, Palgrave Macmillan. 195 p.

Chen Fachun, Leontovich O., 2020. A Tale of Two Cities: Historical Narratives in the Russian and Chinese Urban Landscapes. Vestnik Volgogradskogo gosudarstvennogo universiteta. Seriya 2. Yazykoznanie [Science Journal of Volgograd State University. Linguistics], vol. 19, no. 2, pp. 78-85. DOI: https://doi.org/10.15688/jvolsu2.2020.2.7.

Encyclopedia of Urban Studies, 2010. Green Bay, University of Wisconsin. $1080 \mathrm{p}$.

Fine G.A., Kleinman S., 1979. Rethinking Subculture: An Interactionist Analysis. American Journal of Sociology, vol. 85, no. 1, pp. 1-20.

Galushina N.S., 2016. Subkultury: yazyki opisaniya v menyayushchihsya sociokulturnyh kontekstah [Subcultures: Description Languages in the Changing Sociocultural Contexts]. RSUH/ RGGU Bulletin: Literary Theory. Linguistics. Cultural Studies, vol. 11, no. 2, pp. 120-135. DOI: 10.28995/2686-7249-2016-2-120-135.

Gurevich P.S., 1998. Subkultura [Subculture]. Kul turologiya. XX vek.V2 t. T. 2 : enciklopediya [Cultural Studies. $20^{\text {th }}$ Century. In 2 Vols. Vol. 2. Encyclopedia]. Saint Petersburg, Universitetskaya kniga Publ., pp. 450-453.

Hall S., Jefferson T., eds., 2006. Resistance Through Rituals: Youth Subcultures in Post-War Britain. London, Routledge. 292 p.

Kotelnikova N.N., 2019. Molodezhnye subkul'tury $\mathrm{v}$ mediaurbanisticheskom prostranstve sovremennogo kitayskogo goroda [Youth Subcultures of a Modern Chinese City in the Context of Urban Communication Studies]. Gumanitarnye issledovaniya v Vostochnoy Sibiri i na Dal'nem Vostoke [Humanities Research in the Russian Far East], vol. 1, pp. 25-32. DOI: 10.24866/1997-2857/2019-1/25-32.

Kvyat A.G., 2013. Novye kommunikativnye praktiki v rossiyskih gorodakh [New Communication Practices in Russian Cities]. Dzyaloshinskiy I.M., Pil'gun M.A., eds. Razvitiye russkoyazychnogo mediaprostranstva: kommunikatsionnye $i$ eticheskie problemy: materialy nauch.-prakt. konf. [Development of the Russian-Language Media Space: Communication and Ethical Problems. Conference Materials]. Moscow, Izd-vo APK i PPRO, pp. 351-360.

Kvyat A.G., 2014. Istoriya zarubezhnykh gorodskikh kommunikativnykh issledovaniy [The History of Foreign Urban Communication Studies]. Mediaskop [Mediascope], vol. 4. URL: http:// www.mediascope.ru/1598.

Lefebvre H., 1991. The Production of Space. Malden, Blackwell. 464 p. (Original work published in 1974).
Leontovich O.A., 2018. The All-Seeing Eye of the City from the Perspective of Urban Communication Studies. Vestnik Volgogradskogo gosudarstvennogo universiteta. Seriya 2. Yazykoznanie [Science Journal of Volgograd State University. Linguistics], vol. 17, no. 4, pp. 206-213. DOI: https://doi. org/10.15688/ jvolsu2.2018.4.20.

Leontovich O.A., 2019. New Forms of Urban Discourse As a Reflection of Social Change. Communication Studies, vol. 6, no. 3, pp. 645-654. DOI: 10.25513/2413-6182.2019.6(3).645-654.

Leontovich O.A., 2020. Yazyk bolshogo goroda: klyuchevye problemy mediaurbanistiki [Language of a Big City: Key Issues of Urban Communication Studies]. Etnopsikholingvistika [Ethnopsycholinguistics], vol. 3, pp. 19-34. DOI: 10.31249/epl/2020.03.02.

Levikova S.I., 2007. Molodezhnaya kul'tura [Youth Culture]. Moscow, Vuzovskaya kniga. 360 p.

Mellor J.R., 1977. Urban Sociology in an Urbanized Society. London, Routledge \& Kegan Paul. 328 p.

Omelchenko E.L., 2000. Molodezhnye kul'tury $i$ subkul'tury [Youth Cultures and Subcultures]. Moscow, Institut sotsiologii RAN Publ. 262 p.

Parker S., 2015. Urban Theory and the Urban Experience. Encountering the City. London, New York, Routledge. 290 p.

Pratt A.C., 2011. The Cultural Contradictions of the Creative City. City, Culture and Society, vol. 2, iss. 3, pp. 123-130.

Sikevich Z.V., 1990. Molodezhnaya kul'tura: «za» $i$ «protiv»: Zametki sotsiologa [Youth Culture: "For" and "Against": Notes of a Sociologist]. Leningrad, Lenizdat Publ. 206 p.

Simmel G., 1950. Metropolis and Mental Life. Sociology of Georg Simmel. Chicago, Free Press. 523 p. (Original work published in 1903).

Tarantino M., Tosoni S., 2013. Media and the Social Production of Urban Space: Towards an Integrated Approach Towards the Controversial Nature of Urban Space. Media \& The City: Urbanism, Technology, Communication. S. 1., Cambridge Scholar Publishing, Newcastle Upon Tyne, pp. 2-31. URL: http://hdl.handle. net $/ 10807 / 46851$.

The Charter of the New Urbanism. URL: https.www. cnu.org/who-we-are/charter-new-urbanism.

Weber M., 1966. General Economic History. New York, Collier Books. 288 p. (Original work published in 1923).

Weber M., 1978. The City (Non-Legitimate Domination). Economy and Society: An Outline of Interpretive Sociology. Berkeley, University of California Press, vol. 2, part 16, pp. 1212-1372 (Original work published in 1922).

Wu Yao, 2017. Sravnitelnyi analiz sotsialnykh struktur Rossii i Kitaya [Comparative Analysis of Russian 
and Chinese Social Structures]. Obshchestvo: sociologiya, psihologiya, pedagogika [Society: Sociology, Psychology, Ppedagogics], vol. 5, pp. 57-60.

Yunakovskaya A.A., 2011. "Jazyk goroda" kak lingvisticheskaja problema ["City Language" As Linguistic Problem]. Vestnik Omskogo universiteta [Herald of Omsk University], vol. 3, pp. 193-197.

蔡骐 (Cai Qi), 谢莹 (Xie Ying), 2008. 从“恶搞福 娃”现象反思网络恶搞风潮 [Rethinking the Internet Spoof "egao" from the Phenomenon of “Pranking Fuwa”]. 信息网络安全 [Information Network Security], vol. 6, pp. 50-52.

高丙中 (Gao Bingzhong), 1997。主文化、亚文 化、反文化与中国文化的变迁 [Changes in Mainstream Culture, Subcultures, Countercultures and Chinese Culture]. 社会学研究 [Social Science Research], vol. 1, pp. 113-117.

胡疆锋 (Hu Jiangfeng), 2008. 恶搞与青年亚文化 [Egao and Youth Subculture]. 中国青年研究 [China Youth Study], vol. 6, pp. 5-10.

刘黎黎 (Liu Lili), 2013. “小清新”风格的亚文化解 读 [Sub-Cultural Understanding of Fresh and Aestheticism Style]. 艺术百家 [A Hundred Schools in Art], vol. 1, pp. 71-73.

流响 (Liu Xiang), 2014. “飞特族”的光与影 [The Light and Shadow of the "Feitezu”]. 高中生: 职教与就业 [High School Students: Vocational Education and Employment], vol. 7, pp. 16-17.

庞彦 (Pang Yan), 2011. 浅谈城市涂鸦在中国的 合法性 [Talking About the Legality of Urban Graffiti in China]. 文艺生活 [Literature Life], vol. 3, pp. 181-183.

社会科学大词典 [Social Science Dictionary], 1989. 彭克宏主编. 北京: 中国国际广播出版社 [Beijing, China International Radio Press]. S. 1., s. n. 1279 p.

谯燕 (Qiao Yan), 2012. 传媒新词“御宅族”分析 [The Analysis of the New Media Word “otaku”]. 新闻 与传播研究 [Mass Communication Research], vol. 3, pp. 5-6.

王福帅 (Wang Fushuai), 杨阳 (Yang Yang), 2014. 对“杀马特”现象的理解与反思 [Understanding of the Phenomenon of “Shamate”]. 青年与社会 [Youth and Society], vol. 5, pp. 336-337.
王思妮 (Wang Sini), 2010. 对网络新词语“X族”的 替换分析 [The Analysis of the New Network Word “X Zu”]. 北方文学 [Northern Literature], vol. 9, pp. 87-88.

王晓静 (Wang Xiaojing), 2010. “族”与“族”类词浅析 ["Family" and "Family" Category Words]. 传奇. 传记文学选刊 [Legend. Biography Literary Selection], vol. 7, pp. 35-37.

肖遥遥 (Xiao Yaoyao), 2009. “族”类汉语新词语 法化浅析 [Grammatical Analysis of Chinese Neologisms with the Morpheme "Family"]. 中 州大学学报 [Journal of Zhongzhou University], vol. 2, pp. 75-77.

许苏民 (Xu Sumin), 1990. 文化哲学 [Philosophy of Culture]. 上海人民出版社 [Shanghai, Shanghairen Chubanshe]. 317 p.

“月光族”变“月欠族” 不少年轻人靠借贷消费度日 ["Yueguangzu” Becoming "Yueqianzu". A Lot of Young People Use Loans for Living Expenses], 2019. 新浪财经 [Sina Finance]. URL: http:// finance.sina.com.cn/roll/2019-02-19/docihqfskcp6484532.shtml.

曾丹 (Zeng Dan), 2010. 试析新词语“钟摆族” [The Analysis of the Neologism "Pendulum Clan”]. 现代语文(语言研究版) [Modern Language (Language Research Edition)], vol. 11, pp. 147-148.

张洪涛 (Zhang Hongtao). 30 名昆明年轻人中就 有 9 个“月欠族” [Nine of 30 Kunming Young People Are “Yueqianzu”]. 都市时 报数字报 [The Metropolitan Times Digital Newspaper], 02.03.2019. URL: http://times. clzg.cn/html/2019-03/02/content_106180.htm.

张林 (Zhang Lin), 2014. 网络恶搞现象分析 [The Analysis of the Egao Phenomenon in the Network]. 青年与社会 [Youth and Society], vol. 13, pp. 338-339.

赵声馗 (Zhao Shengkui), 2014. “蚁族”社会资本的缺 失与建构 [The Construction of Social Capital of “Ant Tribe”]. 河北青年管理干部学院学报 [Journal of Hebei Youth Administrative Cadres College], vol. 6, pp. 7-11.

139 万人次参加中国国际动漫节 $[1.39$ Million People Took Part in the China International Anime Festival], 2017. URL: http://www.xinhuanet.com/ politics/2017-05/03/c_129585203.htm. 


\section{Information About the Authors}

Olga A. Leontovich, Doctor of Sciences (Philology), Professor, Head of the Department of Intercultural Communication and Translation, Volgograd State Socio-Pedagogical University, Prosp. Lenina, 27, 400005 Volgograd, Russia; Professor, Tianjin Foreign Studies University, Machang Road, 117, Tianjin, China, olgaleo@list.ru, https://orcid.org/0000-0002-0972-4609

Nadezhda N. Kotelnikova, Candidate of Sciences (Pedagogy), Associate Professor, Department of Intercultural Communication and Translation, Director of Confucius Institute, Volgograd State SocioPedagogical University, Prosp. Lenina, 27, 400005 Volgograd, Russia, kotelnikova_n_n@yahoo.com, https://orcid.org/0000-0001-9900-1983

\section{Информация об авторах}

Ольга Аркадьевна Леонтович, доктор филологических наук, профессор, заведующая кафедрой межкультурной коммуникации и перевода, Волгоградский государственный социальнопедагогический университет, просп. Ленина, 27, 400005 г. Волгоград, Россия; профессор, Тяньцзиньский университет иностранных языков, ул. Мачандао, 117, г. Тяньцзинь, Китай, olgaleo@ list.ru, https://orcid.org/0000-0002-0972-4609

Надежда Николаевна Котельникова, кандидат педагогических наук, доцент кафедры межкультурной коммуникации и перевода, директор Института Конфуция, Волгоградский государственный социально-педагогический университет, просп. Ленина, 27, 400005 г. Волгоград, Россия, kotelnikova_n_n@yahoo.com,https://orcid.org/0000-0001-9900-1983 